\title{
Asymmetry in Volatility: A Comparison of Developed and Transition Stock Markets
}

\author{
Piotr Wdowiński \\ Marta Malecka
}

\author{
CESIFO WORKING PAPER NO. 2974 \\ CATEGORY 7: MONETARY POLICY AND INTERNATIONAL FINANCE \\ MARCH 2010
}

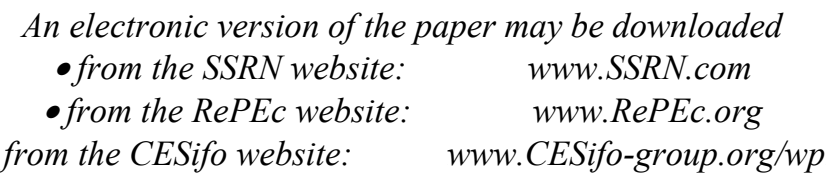




\title{
Asymmetry in Volatility: A Comparison of Developed and Transition Stock Markets
}

\begin{abstract}
ARCH modelling framework of Engle (1982) and its GARCH generalization of Bollerslev (1986) gave a huge impetus to econometric model building in the field of financial time series with time-varying variance. The main idea of the models was to describe the most typical features of capital markets like volatility clustering, excess kurtosis and fat tails. As empirical evidence shows asymmetry is also a prominent feature of stock market returns volatility. The reaction of risk if stock returns go off the long run trajectory is different in case of positive and negative market news. Thus it is indispensable to employ asymmetric models being a modification of a traditional GARCH. In the paper we used an approach of Engle and $\mathrm{Ng}$ (1993) to test for asymmetric effects in stock indices of developed and Central European stock markets.
\end{abstract}

JEL-Code: C10, G15.

Keywords: asymmetry, volatility, stock market, transition.

Piotr Wdowiński

Department of Econometrics

University of Lódź

Poland

piotrw@uni.lodz.pl
Marta Malecka

Department of Statistical Methods

University of Lódź

Poland

marta.malecka@uni.lodz.pl 


\section{Asymmetry in volatility: a comparison of developed and transition stock markets}

\section{Introduction}

Forecasting volatility of financial returns is important for market agents in portfolio selection and pricing of derivatives. ARCH modelling framework of Engle (1982) and its GARCH generalization of Bollerslev (1986) gave a huge impetus to econometric modelling in the field of financial time series with time-varying variance. The main idea of the models was to describe the most typical features of capital markets like volatility clustering, excess kurtosis and fat tails. There is a comprehensive literature on predictability of asset prices and their volatility (see e.g. Bollerslev et al. 1992).

Since the inception of ARCH and GARCH modelling framework, many modifications of the basic approach were proposed. They are either purely theoretically- or empirically-oriented. In the latter case there is a feedback between academic research and the market itself. Being applied in practice, models affect comprehension of financial processes. All new models seek for a proper specification of conditional volatilities. They are motivated by the studies on the nature of financial markets (see e.g. Black 1976, Christie 1982, French, Schwert and Stambaugh 1987, Schwert 1990, Nelson 1991).

One of the prominent characteristics of financial time series is asymmetry in stock returns volatility. As empirical evidence shows, the reaction of risk if stock returns go off the long run trajectory is different in case of positive and negative market news. A stock market overreaction hypothesis states that the asymmetry property is attributable to mispricing behaviour of investors who appear to consistently overreact to specific market news, especially to bad ones (Liau and Yang 2008).

\footnotetext{
* Ph.D., Assistant Professor, Department of Econometrics, University of Łódź, Poland.

** Assistant, Department of Statistical Methods, University of Łódź, Poland.
} 
Commonly two sorts of asymmetry are distinguished. The first type characterizes directly the distribution of returns: the tendency in the stock markets is that positive returns are dominant while negative ones prevail in their magnitude. The second type of asymmetry relates to non-symmetric reactions of volatility to good and bad news represented by the shocks in financial time series. Despite a clear line between the two definitions of asymmetry, the interconnections in the market do not allow to study the two asymmetric components separately. Asymmetric effects of shocks on volatility mean that dropping stock prices boost the volatility, which, in turn, makes the stock more risky. Higher risk premium is then demanded, translating into subsequent price downswings. Resulting large negative deviations influence the asymmetric shape of the returns distribution (Fiszeder 2001).

The asymmetry has been studied extensively regarding valuation of stocks and derivative instruments (see e.g. Merton 1980, Hull and White 1987, Schwert and Seguin 1990, Baillie and Myers 1991, Ng, Engle and Rothschild 1992). Asymmetric volatility fluctuations can be captured in the specification of the conditional variance. Thus in many cases it is indispensable to employ asymmetric models being a modification of a traditional GARCH.

A unified approach to modelling stock returns in capital markets of emerging and developed countries was subject to some criticism (see e.g. Koutmos, Pericli, Trigeorgis 2006) - there is evidence that, although main patterns stay the same, emerging markets behave in a more unstable manner.

The aim of this paper is to present an analysis of volatility clustering and asymmetry. Bearing in mind the linkages between volatility and returns distributions, we focus on modelling asymmetric effect of shocks on the volatility. A comparative analysis is presented with regard to two groups of stock markets - of developed and transition economies.

In this paper we used two models - GARCH and exponential GARCH (EGARCH). The latter was originally proposed by Nelson (1991). To test for asymmetric effects in stock indices of developed and Central European stock markets we used an approach of Engle and Ng (1993). 
The paper is organized as follows. In Section 1 we present the models and testing procedures used throughout the paper. In Section 2 we refer to data issues and introduce preliminary testing to raw data. Section 3 contains testing for asymmetry in GARCH models and final section concludes.

\section{The methodology}

Let $r_{t}$ be the rate of return of a stock index in time $t$. Let $F_{t-1}$ denote an information set of relevant variables up to time $t-1$. The conditional expected value, given $F_{t-1}$, is defined as $\mu_{t}=E\left(r_{t} \mid F_{t-1}\right)$. The conditional variance of $r_{t}$, given $F_{t-1}$, is defined as $h_{t}=\operatorname{Var}\left(r_{t} \mid F_{t-1}\right)$.

The basic $\operatorname{GARCH}(p, q)$ model of Bollerslev (1986), being an infinite order ARCH model of Engle (1982) is as follows (see e.g. Davidson and MacKinnon 2003):

$$
\begin{gathered}
r_{t}=\mu_{t}+u_{t}, \\
u_{t}=\sqrt{h_{t}} \varepsilon_{t}, h_{t} \equiv E\left(u_{t}^{2} \mid F_{t-1}\right), \\
h_{t}=\omega+\sum_{i=1}^{q} \alpha_{i} u_{t-i}^{2}+\sum_{j=1}^{p} \delta_{j} h_{t-j},
\end{gathered}
$$

where $\omega, \alpha_{i}$ and $\delta_{j}$ are constant parameters and $\varepsilon_{t} \sim N(0,1)$. In the GARCH model the news impact curve (Engle and Ng 1993), i.e. the function that relates past return shocks (unexpected returns) to current volatility is a quadratic function centered at $\varepsilon_{t-1}=0$. Hence, positive and negative $u^{\prime} s$ of equal size have the same impact on volatility. If asymmetry is an important feature of returns volatility, an alternative model should be used. Within the ARCH family there are many competing models designated to capture asymmetry in volatility, with EGARCH and GJR (Glosten, Jagannathan and Runkle 1993) specifications being most commonly used in the literature. The main difference between the two approaches is whether the reaction of volatility to market news is quadratic (GJR) or exponential (EGARCH). As the aim of our paper is not to test one specification versus another, basing on some 
recent empirical results, we employed an EGARCH model for asymmetry analysis (Dima, Haim and Rami 2008, McAleer 2007).

The EGARCH model is given as follows (Nelson 1991):

$$
\begin{gathered}
r_{t}=\mu_{t}+u_{t}, \\
u_{t}=\sqrt{h_{t}} \varepsilon_{t}, h_{t} \equiv E\left(u_{t}^{2} \mid F_{t-1}\right), \\
\log \left(h_{t}\right)=\omega+\beta \log \left(h_{t-1}\right)+\gamma \frac{u_{t-1}}{\sqrt{h_{t-1}}}+\alpha\left[\frac{\left|u_{t-1}\right|}{\sqrt{h_{t-1}}}-\sqrt{\frac{2}{\pi}}\right],
\end{gathered}
$$

where $\omega, \beta, \gamma$ and $\alpha$ are constant parameters and $\varepsilon_{t} \sim N(0,1)$. In the EGARCH model the news impact curve is an exponential function. It has a minimum at $\varepsilon_{t-1}=0$ and is increasing in both directions but with different parameters. Hence it captures asymmetric behavior of time series as it allows positive and negative unexpected returns to have a different impact on volatility. The advantage of EGARCH methodology is that it facilitates a simultaneous investigation of the asymmetric impact of positive and negative news on stock returns volatility (Verma and Jackson 2008). Furthermore, the specification of conditional variance captures the size effects as it allows excess unexpected returns to have a greater impact on volatility.

For a comparative analysis we will use a standard GARCH model followed by an EGARCH approach within three specifications of the conditional mean $\mu$. They are the following:

$$
\begin{gathered}
r_{t}=a+u_{t}, \\
r_{t}=b_{0}+b_{1} r_{t-1}+u_{t}, \\
r_{t}=c_{0}+c_{1} \bar{r}_{t-s}+u_{t},
\end{gathered}
$$

where: $a, b_{0}, b_{1}, c_{0}, c_{1}$ are constant parameters, $\bar{r}_{t-s}$ is a return on Dow Jones index, $s \geq 0$. Equation (9) is a stylized single-index Sharpe model.

To accommodate the potential asymmetry in volatility of returns on stock indices which is not captured by the underlying models we used the conditional variance misspecification tests of Engle and $\mathrm{Ng}$ (1993). 
The diagnostic tests, the Sign Bias Test (SBT), the Negative Size Bias Test (NSBT), the Positive Size Bias Test (PSBT) and the joint test examine whether the squared normalized residual $\varepsilon_{t}$ can be predicted with additional variables not explicitly included in a particular conditional volatility function.

Let $\varepsilon_{t}=u_{t} / \sqrt{h_{t}}$ be the normalized residual which corresponds to a particular volatility model. The SBT considers a dummy variable $S_{t-1}^{-}$ that takes a value of one when $u_{t-1}<0$ and zero otherwise. The NSBT uses the variable $S_{t-1}^{-} u_{t-1}$. The PSBT utilizes the variable $S_{t-1}^{+} u_{t-1}$ where $S_{t-1}^{+}$is defined as $1-S_{t-1}^{-}$. Hence the testing regressions are given respectively:

$$
\begin{gathered}
\varepsilon_{t}^{2}=\theta_{0}+\theta_{1} S_{t-1}^{-}+\xi_{t}, \\
\varepsilon_{t}^{2}=\theta_{0}+\theta_{1} S_{t-1}^{-} u_{t-1}+\xi_{t}, \\
\varepsilon_{t}^{2}=\theta_{0}+\theta_{1} S_{t-1}^{+} u_{t-1}+\xi_{t},
\end{gathered}
$$

where $\theta^{\prime} s$ are constant parameters and $\xi$ denotes the residual. The tests can be conducted jointly as follows:

$$
\varepsilon_{t}^{2}=\theta_{0}+\theta_{1} S_{t-1}^{-}+\theta_{2} S_{t-1}^{-} u_{t-1}+\theta_{3} S_{t-1}^{+} u_{t-1}+\xi_{t},
$$

where $\theta_{i}, i=0, \ldots, 3$ are constant coefficients and $\xi$ is the residual. If the volatility model being used is correct, then $\theta_{i}=0, i=1,2,3$ and $\xi$ is i.i.d. The tests are the LM tests and the statistics follow a $\chi^{2}(1)$ distribution in (10)-(12) and $\chi^{2}(3)$ in (13).

\section{The data and preliminary testing}

In the research we used the data on daily close-to-close logarithmic returns $r_{t} \equiv 100\left(\log y_{t}-\log y_{t-1}\right)$ for six indices of developed and six of transition economies, namely:

- Canada - TSX,

- France-CAC40,

- Germany - DAX, 
- Italy - MIBTEL,

- United Kingdom - FTSE100,

- Japan - NIKKEI225,

- Hungary - BUX,

- Poland - WIG20,

- Russia - RTS,

- Slovakia - SAX,

- Slovenia - SBI20,

- Baltic Republics (Estonia, Latvia, Lithuania) - OMXBGI.

The sample starts at the beginning of 2005 and ends at the beginning of 2008. Due to the financial crisis of the year 2008 and resulting substantial instability in capital markets, inclusion of this year into the sample might have a strong impact on our results. We leave performance of presented methods in times of instability as an issue for further research.

In Tab. 1 we presented basic descriptive statistics of the time series. There is a clear difference between the two groups of countries with respect to central tendency measures and measures of dispersion. Mean returns in Central European economies (CEE) are generally higher which is followed by also higher standard deviations. There is a clear economic interpretation saying that for investing in more risky markets we get higher return with high volatility being the cost. Without an exception, index returns are leptokurtic and exhibit asymmetry to the left, which depicts typical aspects of investing in capital markets. There is a noticeable difference in magnitude of coefficients of asymmetry between the two surveyed groups of countries. In transition economies these coefficients tend to have slightly lower values. Through the relations between asymmetric character of volatility and asymmetry of returns probability distributions, this may suggest that different approaches are required to model conditional variance in the two groups of markets. Jarque-Bera statistics show significant departures from a normal distribution, being also an evidence of outliers and fat tails. Ljung-Box (LB) test conducted on return levels and squares suggests a strong presence of serial correlation. This is especially the case of squared returns giving a first evidence of conditional heteroskedasticity. 
The diagnostic misspecification tests given in the previous section can also be applied to raw data without first imposing a conditional volatility model. Such approach allows for a quick overview of the data before deciding on the more complex machinery to be employed. Given the properties of these diagnostic tests however, they should be treated as preliminary summary statistics rather than final tests of asymmetry (Engle and Ng 1993).

Let $u_{t} \equiv r_{t}-\mu$ and $\varepsilon_{t} \equiv u_{t} / \sigma$, where $\mu$ and $\sigma$ are the unconditional mean and standard deviation of $r_{t}$, respectively. Tab. 2 presents the results of the tests. As NSB test shows, stock returns seem sensitive to lagged values which are lower than the mean. Both individual and joint tests with low probability values detected asymmetry in many cases, giving an incentive to employ asymmetric models framework. However, interpretation of the tests depends on properties of residuals from conducted regressions. Diagnostic tests, namely a Ljung-Box test with 10 lags and a White test, indicate the presence of serial correlation and, in some cases, heteroskedasticity in these residuals. In this case the tests may be biased, which calls for a careful interpretation of the results. 


\begin{tabular}{|l|rrrrrrr|}
\hline & Mean (\%) & Median (\%) & Max (\%) & Min (\%) & St. dev. (pp) & Skew. & Kurtosis \\
\hline BUX & 0,06 & 0,08 & 4,87 & $-5,38$ & 1,41 & $-0,16$ & 3,90 \\
OMX & 0,08 & 0,10 & 6,06 & $-4,44$ & 0,78 & 0,00 & 15,85 \\
RTS & 0,22 & 0,26 & 6,53 & $-5,87$ & 1,51 & $-0,23$ & 4,91 \\
SAX & 0,06 & 0,02 & 4,07 & $-4,67$ & 0,97 & $-0,29$ & 7,98 \\
SBI & 0,14 & 0,05 & 4,56 & $-3,17$ & 0,80 & 0,14 & 7,30 \\
WIG & 0,05 & 0,05 & 4,76 & $-4,63$ & 1,41 & $-0,12$ & 3,73 \\
\hline CAC & 0,06 & 0,12 & 3,22 & $-3,31$ & 0,94 & $-0,44$ & 4,08 \\
DAX & 0,08 & 0,15 & 2,61 & $-3,46$ & 0,94 & $-0,38$ & 3,67 \\
FTSE & 0,05 & 0,08 & 3,44 & $-4,19$ & 0,87 & $-0,47$ & 5,82 \\
MIBTEL & 0,04 & 0,10 & 2,15 & $-3,25$ & 0,77 & $-0,64$ & 4,38 \\
NIKKEI & 0,03 & 0,01 & 3,60 & $-5,57$ & 1,09 & $-0,26$ & 4,88 \\
TSX & 0,04 & 0,07 & 2,16 & $-2,80$ & 0,81 & $-0,56$ & 3,67 \\
DJ & 0,02 & 0,08 & 2,78 & $-3,30$ & 0,86 & $-0,42$ & 4,09 \\
\hline & & & LB $(10)$ & & LB $(10)$ & & \\
Jif & J-B & p-value & levels & p-value & squares & p-value & No. obs. \\
\hline BUX & 22,56 & 0,00 & 40,74 & 0,00 & 210,47 & 0,00 & 565 \\
OMX & 3983,30 & 0,00 & 52,36 & 0,00 & 48,60 & 0,00 & 579 \\
RTS & 88,64 & 0,00 & 12,43 & 0,26 & 188,37 & 0,00 & 550 \\
SAX & 564,96 & 0,00 & 12,80 & 0,24 & 75,84 & 0,00 & 540 \\
SBI & 427,13 & 0,00 & 36,80 & 0,00 & 167,54 & 0,00 & 551 \\
WIG & 13,77 & 0,00 & 4,06 & 0,95 & 66,32 & 0,00 & 557 \\
\hline CAC & 47,43 & 0,00 & 16,58 & 0,08 & 181,48 & 0,00 & 583 \\
DAX & 24,95 & 0,00 & 16,76 & 0,08 & 93,24 & 0,00 & 583 \\
FTSE & 212,49 & 0,00 & 13,37 & 0,20 & 268,14 & 0,00 & 578 \\
MIBTEL & 84,15 & 0,00 & 19,52 & 0,03 & 96,37 & 0,00 & 570 \\
NIKKEI & 86,91 & 0,00 & 17,56 & 0,06 & 90,85 & 0,00 & 551 \\
TSX & 37,45 & 0,00 & 7,57 & 0,67 & 43,20 & 0,00 & 530 \\
DJ & 46,08 & 0,00 & 10,97 & 0,36 & 131,93 & 0,00 & 583 \\
\hline
\end{tabular}

Tab. 1. Descriptive statistics 


\begin{tabular}{|c|c|c|c|c|c|c|}
\hline & SB & p-value & White & p-value & $\mathrm{LB}(10)$ & p-value \\
\hline BUX & 2,97 & 0,09 & 1,75 & 0,19 & 54,48 & 0,00 \\
\hline OMX & 3,95 & 0,05 & 2,23 & 0,14 & 53,75 & 0,00 \\
\hline RTS & 2,62 & 0,11 & 0,50 & 0,48 & 188,79 & 0,00 \\
\hline SAX & 1,56 & 0,21 & 0,22 & 0,64 & 66,34 & 0,00 \\
\hline SBI & 0,01 & 0,92 & 1,13 & 0,29 & 167,77 & 0,00 \\
\hline WIG & 0,02 & 0,88 & 0,10 & 0,75 & 65,73 & 0,00 \\
\hline$\overline{\mathrm{CAC}}$ & 0,28 & 0,60 & 0,21 & 0,65 & 163,61 & 0,00 \\
\hline DAX & 2,15 & 0,14 & 0,36 & 0,55 & 91,74 & 0,00 \\
\hline FTSE & 1,96 & 0,16 & 2,76 & 0,10 & 263,50 & 0,00 \\
\hline MIBTEL & 2,41 & 0,12 & 0,00 & 0,95 & 92,56 & 0,00 \\
\hline NIKKEI & 1,45 & 0,23 & 0,29 & 0,59 & 90,15 & 0,00 \\
\hline \multirow[t]{2}{*}{ TSX } & 0,08 & 0,77 & 0,12 & 0,73 & 42,74 & 0,00 \\
\hline & PSB & p-value & White & p-value & $\mathrm{LB}(10)$ & p-value \\
\hline BUX & 7,98 & 0,00 & 1,38 & 0,24 & 37,38 & 0,00 \\
\hline OMX & 20,66 & 0,00 & 0,83 & 0,36 & 25,74 & 0,00 \\
\hline RTS & 15,47 & 0,00 & 10,20 & 0,00 & 130,96 & 0,00 \\
\hline SAX & 0,56 & 0,45 & 0,08 & 0,78 & 66,06 & 0,00 \\
\hline SBI & 55,34 & 0,00 & 32,08 & 0,00 & 86,58 & 0,00 \\
\hline WIG & 0,00 & 0,96 & 0,35 & 0,55 & 66,14 & 0,00 \\
\hline $\mathrm{CAC}$ & 5,18 & 0,02 & 0,87 & 0,35 & 143,77 & 0,00 \\
\hline DAX & 5,26 & 0,02 & 0,13 & 0,72 & 75,10 & 0,00 \\
\hline FTSE & 29,40 & 0,00 & 14,74 & 0,00 & 156,03 & 0,00 \\
\hline MIBTEL & 4,73 & 0,03 & 0,61 & 0,44 & 77,50 & 0,00 \\
\hline NIKKEI & 3,72 & 0,05 & 4,30 & 0,04 & 77,73 & 0,00 \\
\hline \multirow[t]{2}{*}{ TSX } & 0,46 & 0,50 & 0,12 & 0,73 & 40,67 & 0,00 \\
\hline & NSB & p-value & White & p-value & $\mathrm{LB}(10)$ & p-value \\
\hline$\overline{B U X}$ & 0,01 & 0,94 & 0,15 & 0,70 & 56,15 & 0,00 \\
\hline OMX & 0,47 & 0,49 & 1,60 & 0,21 & 58,53 & 0,00 \\
\hline RTS & 2,68 & 0,10 & 4,61 & 0,03 & 171,56 & 0,00 \\
\hline SAX & 5,77 & 0,02 & 1,08 & 0,30 & 46,38 & 0,00 \\
\hline SBI & 7,81 & 0,01 & 0,11 & 0,74 & 112,20 & 0,00 \\
\hline WIG & 0,70 & 0,40 & 1,11 & 0,29 & 66,42 & 0,00 \\
\hline$\overline{\mathrm{CAC}}$ & 0,25 & \begin{tabular}{ll|}
0,62 \\
\end{tabular} & 1,20 & 0,27 & 171,88 & 0,00 \\
\hline DAX & 0,13 & 0,72 & 0,59 & 0,44 & 95,82 & 0,00 \\
\hline FTSE & 0,18 & 0,67 & 1,63 & 0,20 & 252,15 & 0,00 \\
\hline MIBTEL & 0,17 & 0,68 & 1,05 & 0,30 & 93,32 & 0,00 \\
\hline NIKKEI & 0,18 & 0,67 & 0,02 & 0,89 & 93,32 & 0,00 \\
\hline \multirow[t]{2}{*}{ TSX } & 1,08 & 0,30 & 0,29 & 0,59 & 45,39 & 0,00 \\
\hline & Joint test & p-value & White & p-value & $\mathrm{LB}(10)$ & p-value \\
\hline BUX & 10,58 & 0,00 & 3,30 & 0,65 & 33,21 & 0,00 \\
\hline OMX & 20,84 & 0,00 & 4,14 & 0,53 & 24,28 & 0,01 \\
\hline RTS & 27,01 & 0,00 & 18,75 & 0,00 & 90,51 & 0,00 \\
\hline SAX & 7,89 & 0,05 & 1,80 & 0,88 & 41,45 & 0,00 \\
\hline SBI & 87,24 & 0,00 & 31,42 & 0,00 & 29,60 & 0,00 \\
\hline WIG & 1,03 & 0,79 & 1,37 & 0,93 & 68,93 & 0,00 \\
\hline $\mathrm{CAC}$ & 7,65 & 0,05 & 4,63 & 0,46 & 119,83 & 0,00 \\
\hline DAX & 5,78 & 0,12 & 0,59 & 0,99 & 70,13 & 0,00 \\
\hline FTSE & 37,05 & 0,00 & 14,18 & 0,01 & 110,94 & 0,00 \\
\hline MIBTEL & 5,42 & 0,14 & 4,67 & 0,46 & 74,04 & 0,00 \\
\hline NIKKEI & 3,93 & 0,27 & 6,15 & 0,29 & 75,52 & 0,00 \\
\hline TSX & 1,83 & 0,61 & 2,27 & 0,81 & 44,42 & 0,00 \\
\hline
\end{tabular}

Tab. 2. Preliminary asymmetry tests 


\section{Testing for asymmetry in stock returns volatility}

Having considered the three specifications of the conditional mean, we applied an ARCH test to residuals $u_{t}$ (Tab. 3). ARCH effects seem to be strongly present in residuals. There is, however, one exception: the TSX index in the Sharpe model. This gives evidence that ARCH effects might be not invariant against a form of the mean specification. The TSX index was the one of special interest as the $\mathrm{ARCH}$ tests results suggest that a linear combination of two ARCH processes may produce a random variable free from conditional heteroskedasticity. Residuals from mean equations in this simple form show also serial correlation, which is another signal of misspecification.

\begin{tabular}{|c|c|c|c|c|c|c|c|c|}
\hline & \multicolumn{2}{|c|}{ CONST } & \multicolumn{3}{|c|}{$\operatorname{AR}(1)$} & \multicolumn{3}{|c|}{ SHARPE } \\
\hline & $a$ & $\mathrm{ARCH}$ test & $b_{0}$ & $b_{1}$ & $\mathrm{ARCH}$ test & $c_{0}$ & $c_{1}$ & $\mathrm{ARCH}$ test \\
\hline \multirow[t]{2}{*}{ BUX } & 0,00 & 33,84 & 0,00 & 0,05 & 33,48 & 0,00 & 0,05 & 33,48 \\
\hline & 0,29 & 0,00 & 0,33 & 0,25 & 0,00 & 0,33 & 0,25 & 0,00 \\
\hline \multirow[t]{2}{*}{ OMX } & 0,00 & 36,83 & 0,00 & 0,16 & 37,80 & 0,00 & 0,22 & 31,99 \\
\hline & 0,01 & 0,00 & 0,04 & 0,00 & 0,00 & 0,02 & 0,00 & 0,00 \\
\hline \multirow[t]{2}{*}{ RTS } & 0,00 & 81,09 & 0,00 & 0,04 & 79,88 & 0,00 & 0,39 & 74,71 \\
\hline & 0,00 & 0,00 & 0,00 & 0,30 & 0,00 & 0,00 & 0,00 & 0,00 \\
\hline \multirow[t]{2}{*}{ SAX } & 0,00 & 48,60 & 0,00 & 0,08 & 48,99 & 0,00 & 0,02 & 49,83 \\
\hline & 0,16 & 0,00 & 0,21 & 0,07 & 0,00 & 0,18 & 0,62 & 0,00 \\
\hline \multirow[t]{2}{*}{ SBI } & 0,00 & 94,53 & 0,00 & 0,16 & 69,93 & 0,00 & 0,15 & 92,43 \\
\hline & 0,00 & 0,00 & 0,00 & 0,00 & 0,00 & 0,00 & 0,00 & 0,00 \\
\hline \multirow[t]{2}{*}{ WIG } & 0,00 & 60,10 & 0,00 & $-0,01$ & 59,70 & 0,00 & 0,23 & 54,81 \\
\hline & 0,44 & 0,00 & 0,42 & 0,88 & 0,00 & 0,46 & 0,00 & 0,00 \\
\hline \multirow[t]{2}{*}{$\mathrm{CAC}$} & 0,00 & 82,16 & 0,00 & $-0,05$ & 82,75 & 0,00 & 0,22 & 95 \\
\hline & 0,10 & 0,00 & 0,09 & 0,24 & 0,00 & 0,12 & 0,00 & 0,00 \\
\hline \multirow[t]{2}{*}{ DAX } & 0,00 & 51,03 & 0,00 & $-0,01$ & 51,05 & 0,00 & 0,24 & 50,68 \\
\hline & 0,04 & 0,00 & 0,04 & 0,89 & 0,00 & 0,05 & 0,00 & 0,00 \\
\hline \multirow[t]{2}{*}{ FTSE } & 0,00 & 103,87 & 0,00 & $-0,08$ & 106,64 & 0,00 & 0,19 & 103,37 \\
\hline & 0,21 & 0,00 & 0,16 & 0,04 & 0,00 & 0,24 & 0,00 & 0,00 \\
\hline \multirow[t]{2}{*}{ MIBTEL } & 0,00 & 54,83 & 0,00 & 0,00 & 54,84 & 0,00 & 0,17 & 60,89 \\
\hline & 0,23 & 0,00 & 0,23 & 0,92 & 0,00 & 0,26 & 0,00 & 0,00 \\
\hline \multirow[t]{2}{*}{ NIKKEI } & 0,00 & 52,88 & 0,00 & $-0,02$ & 51,35 & 0,00 & 0,44 & 41,61 \\
\hline & 0,52 & 0,00 & 0,49 & 0,59 & 0,00 & 0,50 & 0,00 & 0,00 \\
\hline \multirow[t]{2}{*}{ TSX } & 0,00 & 30,40 & 0,00 & $-0,04$ & 29,06 & 0,00 & 0,63 & 10,78 \\
\hline & 0,24 & 0,00 & 0,20 & 0,35 & 0,00 & 0,21 & 0,00 & 0,37 \\
\hline
\end{tabular}

Tab. 3. Mean equations and $\mathrm{ARCH}$ tests

Having conducted ARCH tests, we moved to estimation of $\operatorname{GARCH}(1,1)$ and $\operatorname{EGARCH}(1,1)$ models for the three models of the conditional mean (7)-(9). Tab. 4 gives details of the GARCH fit. From 
three mean specifications, we obtained best estimates in the stylized Sharpe model. Parameters on DJCA index are significant in most cases, in both groups of countries. As we can see, the country betas (risk) were much below one with an exception of TSX index (0.63). Hence all stock markets appeared to be defensive in terms of the American market. There were clear spillover effects of the US market into other markets with stronger effects for developed economies.

The models are consistent with the results of ARCH tests described above. In all cases, parameters $\alpha$ and $\delta$ (or at last $\delta$ alone) are statistically significant, indicating dependence of volatility on squared past deviations from the mean. Comparison of the three approaches to GARCH modelling (7)-(9) shows that the estimates obtained for the conditional variance equation are not invariant against the form of the mean specification. The variant with a systematic factor of the DJCA index gives a bit lower $\alpha$ 's. This may be an argument for a systematic approach to mean specification allowing for separation of spillover effects of US market from volatility clustering effects (Chen et al. 2006).

Basic diagnostic tests show that with GARCH specification we eliminated serial correlation, conditional and unconditional heteroskedasticity from residuals. Consecutively, we applied the four volatility misspecification tests on normalized residuals of the particular volatility model.

Misspecification test results are given in Tab. 5. The parameters on additional variables we test are, in most cases, not statistically significant, which suggests that GARCH model performed reasonably well in describing volatile processes in the studied markets. Consequently, including asymmetric variables under question would not bring much change to the goodness of fit. However, there are a few cases in which we can see statistical significance of additional variables at $10 \%$ level of significance, which accommodate news size effects. This gives an incentive to build asymmetric models for comparison. 


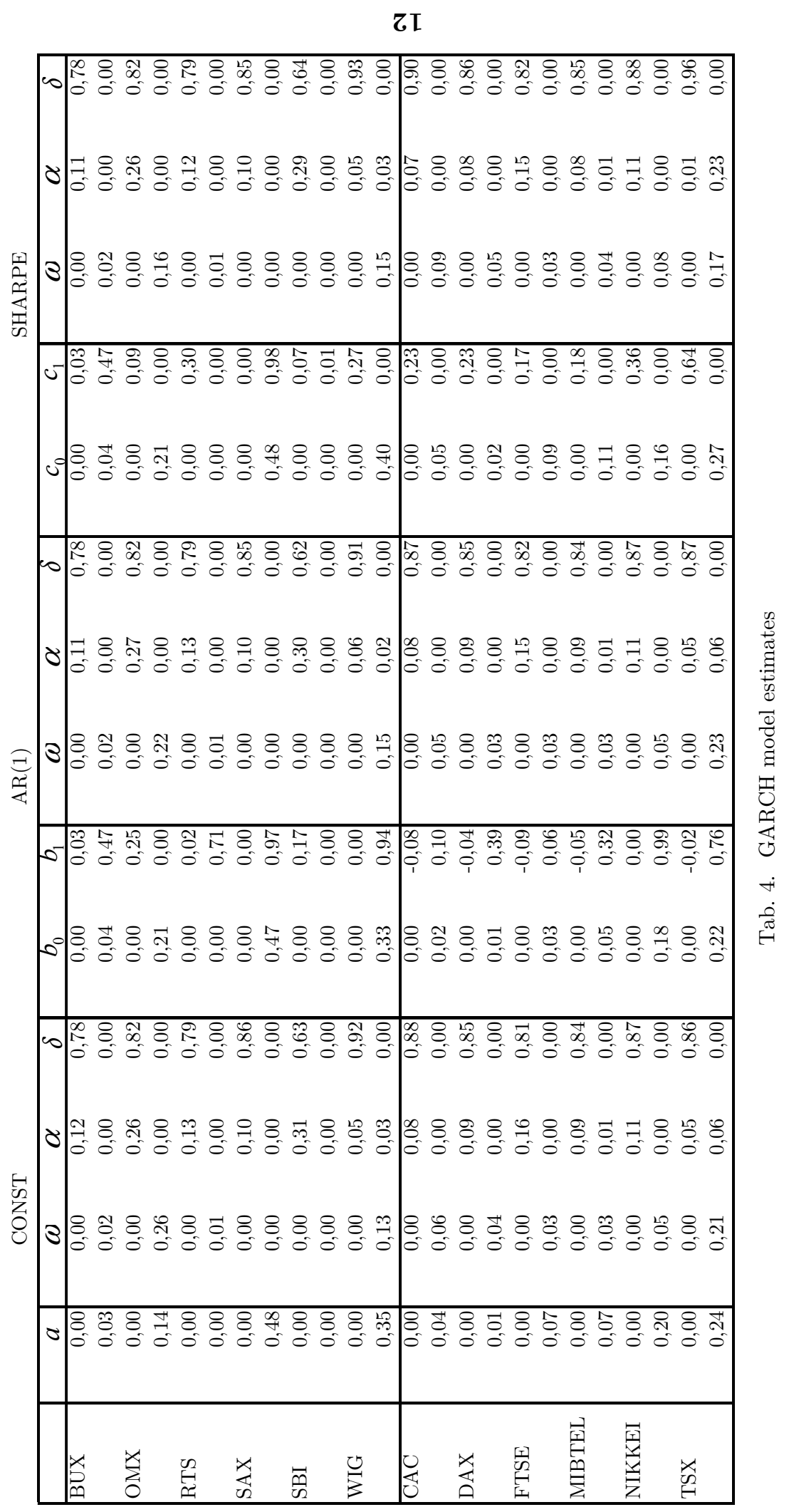




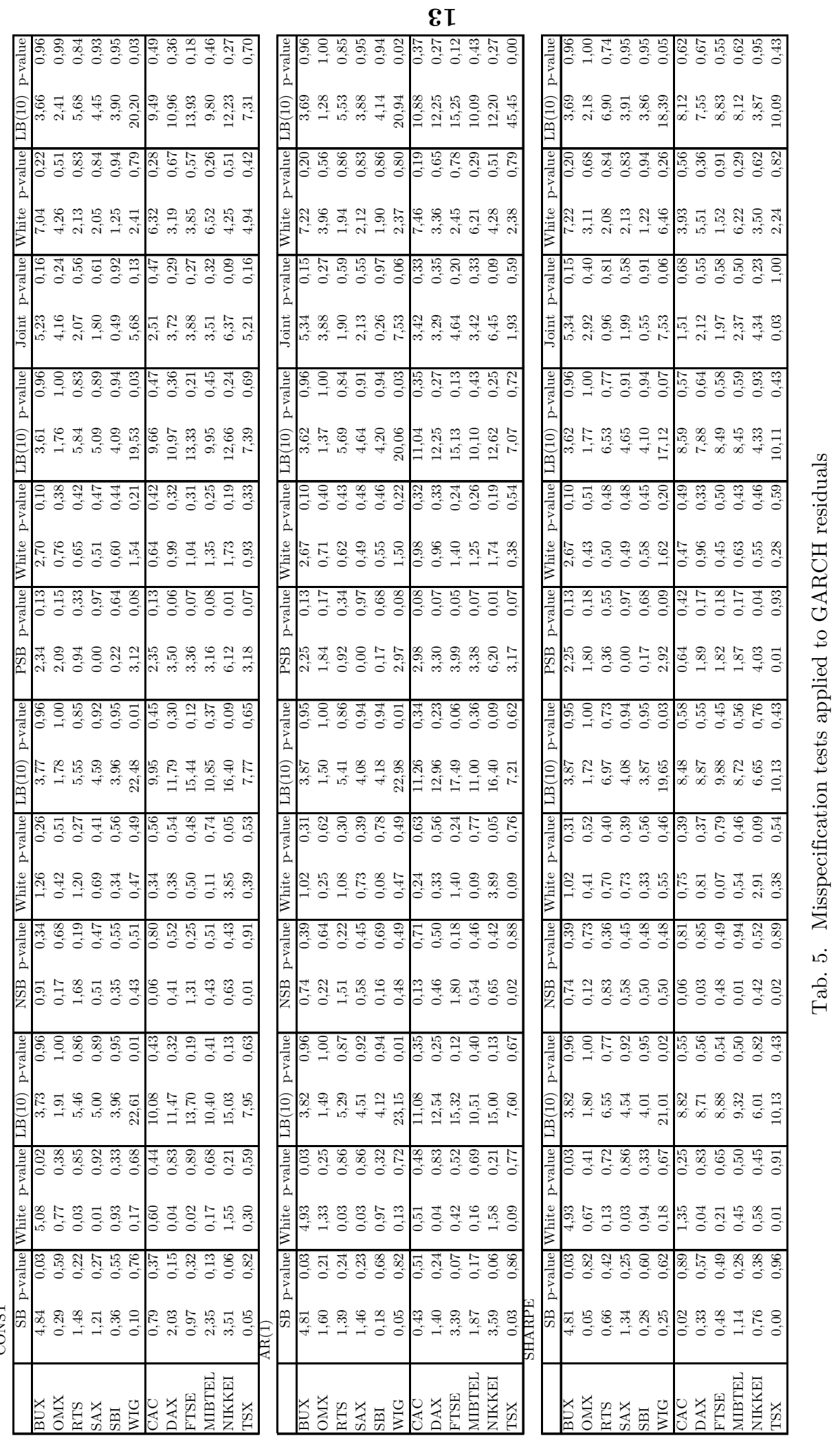


Tab. 6 gives the estimation results of the EGARCH specification. A parameter responsible for asymmetry is $\gamma$. In most cases it is negative. Stronger effects can be seen in developed countries. For the TSX again it seems that all predictable effects were already included in the DJCA index. The asymmetric behaviour of returns volatility in transition countries was not that typical. EGARCH specification seems to model best the BUX index. For the RTS and SBI, parameters significance in the conditional variance equation varies depending on the mean specification. Sharpe model seems reasonable for Moscow index, while AR(1) model gives the best fit for SBI. Based on $10 \%$ significance level, it is possible that there are some asymmetric effects. However, they may be more difficult to capture in the form of an EGARCH model. Other three indices, WIG20, SAX and OMX probably exhibit no typical asymmetry, as $\gamma$ parameters are either not significant or have the positive sign. However, for the SAX the problem may be with a good specification of the mean, which affects conditional variance equation. Another solution would be employing a different asymmetric models (see e.g. Hansson and Hördahl 2005 for VS-GARCH model of the OMX index and Miłobędzki 2006 for different asymmetric models of the WIG index). Additionally, some improvements could be possibly achieved by adopting more realistic assumptions about the error probability distribution prior to the specification of GARCH or EGARCH models.

Generally $\gamma$ 's are rather low, their absolute value fluctuates around 0.1. This means that other elements like specification of the mean and GARCH effects take the bulk of explaining the process of stock returns. This is also consistent with misspecification tests results related to the GARCH fit, saying that the GARCH models performed reasonably well.

Misspecification tests applied to the EGARCH models (Tab. 7) indicate that inclusion of additional asymmetric variables to the conditional variance equation would not bring any extra information. In comparison to tests conducted on GARCH residuals, higher p-values mean that asymmetric approach produced better results and the relevance of $\gamma$ estimates is thus supported. 


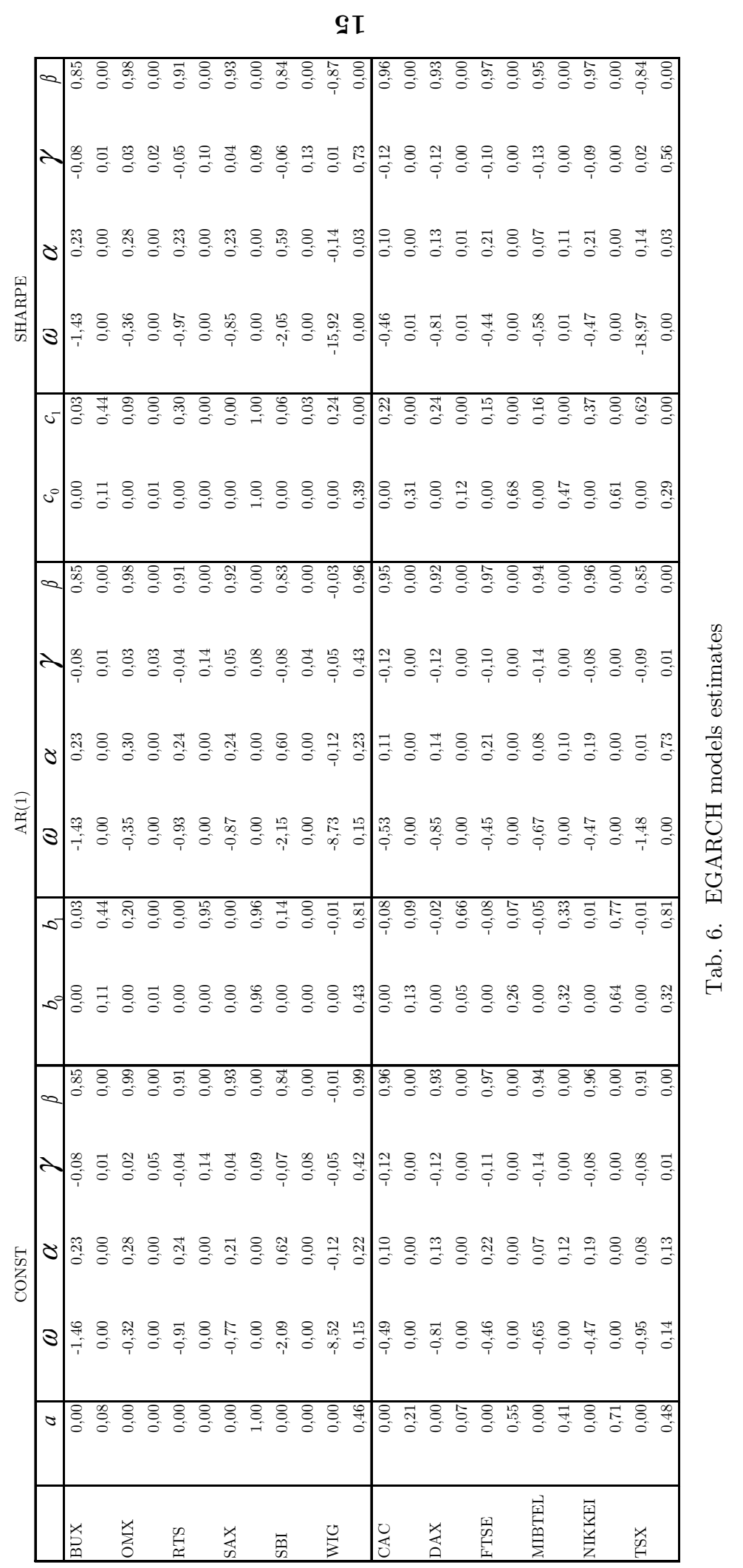




\section{I}

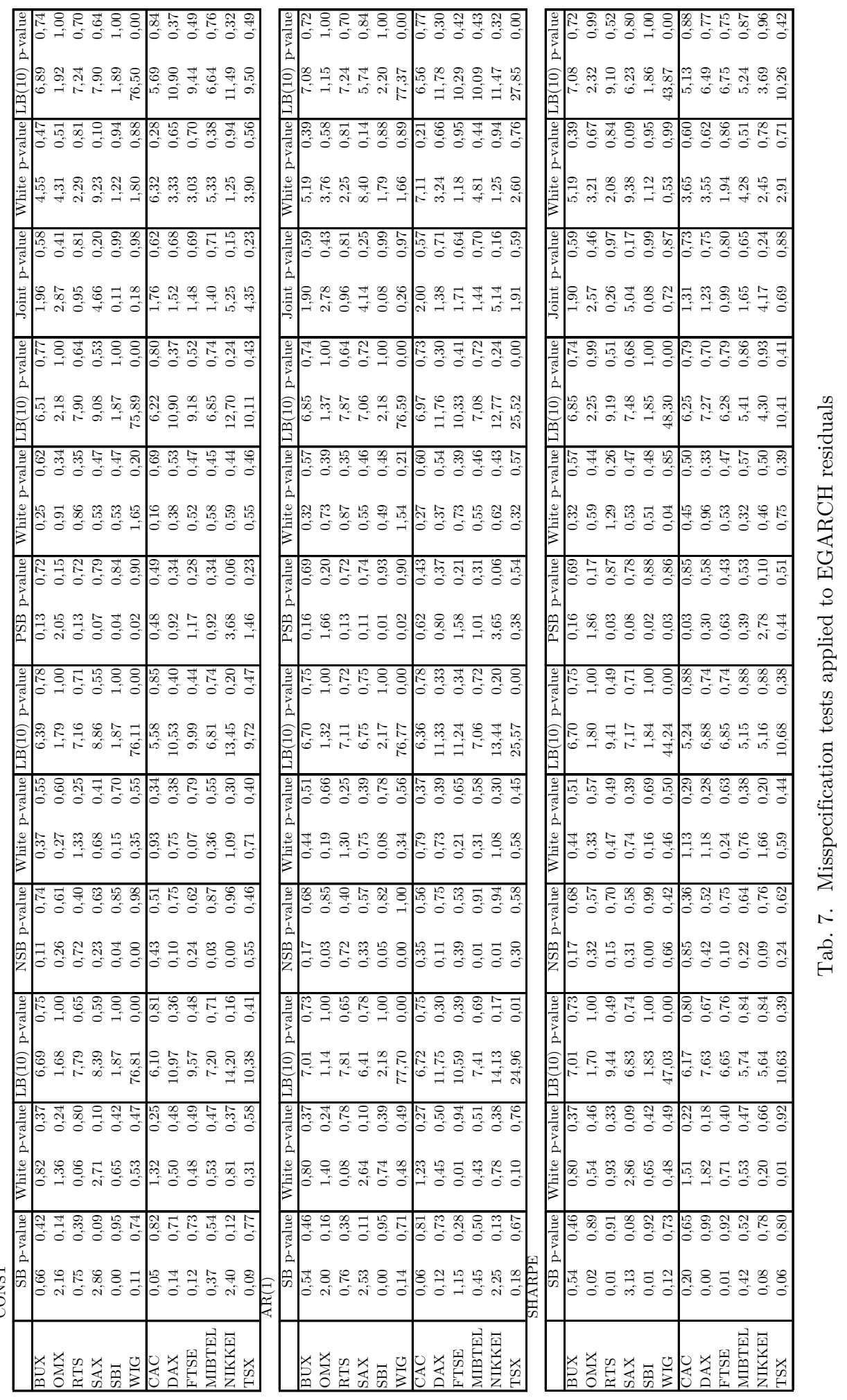




\section{Conclusion}

In the paper we employed a traditional GARCH model of Bollerslev (1986) and its asymmetric modification of Nelson (1991) to describe stock market returns in developed and Central European economies. Additionally we used an approach of Engle and Ng (1993) to test for asymmetric effects in analysed stock indices.

Both the tests and modelling framework gave a clear evidence of volatility clustering in the two groups of stock markets - GARCH approach seemed indispensable. The interpretation of that fact is that large deviations from the trajectory are followed by subsequent large deviations. On the other hand "quiet periods" happen when small deviations breed other small ones. However, in some cases, it was possible to find a specification of a conditional mean that was capable of describing $\mathrm{ARCH}$ effects.

From all analysed indices only the Polish one exhibited no typical asymmetric behavior. Thus a general statement seems justified that market reaction for negative news might be different than that for positive ones. Negative shocks tended to hit harder, i.e. they bred more uncertainty and stronger fluctuations to the market.

EGARCH specification performed well for developed markets, while describing asymmetric behavior in transition economies seems a more challenging task. The group of Central European economies is not internally homogenous and it requires a separate effort to model particular index returns. EGARCH parameters in CEE case were estimated with larger errors.

\section{References}

Baillie R., Myers R. (1991), "Modelling Commodity Price Distributions and Estimating the Optimal Futures Hedge," Journal of Applied Econometrics 6, 109-24.

Black F. (1976), "Studies in Stock Price Volatility Changes," Proceedings of the 1976 Business Meeting of the Business and Economics Statistics Section, American Statistical Association, 177-81. 
Bollerslev T. (1986), "Generalized Autoregressive Conditional Heteroskedasticity," Journal of Econometrics 31, 307-27.

Bollerslev T., Chou R., Kroner K. (1992), "ARCH Modelling in Finance: A Review of the Theory and Empirical Evidence," Journal of Econometrics 52, 5-59.

Chen C., Yang M., Gerlach R., Jim L. (2006), "The Asymmetric Reactions of Mean and Volatility of Stock Returns to Domestic and International Information Based on a Four-Regime Double-Threshold GARCH Model," Physica 366, 401-18.

Christie A. (1982), "The Stochastic Behavior of Common Stock Variance: Value, Leverage and Interest Rate Effects," Journal of Financial Economics 10, 40732.

Davidson R., MacKinnon J. G. (2003), Econometric Theory and Methods, Oxford University Press, New York.

Dima A., Haim S., Rami Y. (2008), "Estimating Stock Market Volatility Using Asymmetric GARCH Models," Applied Financial Economics 18, 1201-8.

Engle R. F. (1982), "Autoregressive Conditional Heteroskedasticity with Estimates of the Variance of the UK Inflation," Econometrica 50, 987-1008.

Engle R. F., Ng V. (1993), "Measuring and Testing the Impact of News on Volatility," Journal of Finance 48, 1749-78.

Fiszeder P. (2001), „Zastosowanie modeli GARCH w analizie krótkookresowych zależności pomiędzy warszawską giełdą papierów wartościowych a międzynarodowymi rynkami akcji," Przegląd Statystyczny 48, 345-64.

French K., Schwert G., Stambaugh R. (1987), "Expected Stock Returns and Volatility," Journal of Financial Economics 19, 3-29.

Glosten L. R., Jagannathan R., Runkle D. E. (1993), "On the Relation Between the Expected Value and the Volatility of the Nominal Excess Return on Stocks," Journal of Finance 48, 1779-801.

Hansson B., Hördahl P. (2005), "Forecasting Variance Using Stochastic Volatility and GARCH," European Journal of Finance 11, 33-57.

Hull J., White A. (1987), "The Pricing of Options on Assets with Stochastic Volatilities," Journal of Finance 42, 281-300.

Koutmos G., Pericli A., Trigeorgis L. (2006), "Short-term Dynamics in the Cyprus Stock Exchange," European Journal of Finance 12, 205-16.

Liau Y., Yang J. (2008), "The Mean/Volatility Asymmetry in Asian Stock Markets," Applied Financial Economics 18, 411-19.

McAleer M. (2007), "An Econometric Analysis of Asymmetric Volatility: Theory and Application to Patents," Journal of Econometrics 139, 259-84.

Merton R. (1980), "On Estimating the Expected Return on the Market: An Explanatory Investigation," Journal of Financial Economics 8, 323-61. 
Miłobędzki P. (2006), "Asymmetry in the Adjustment of Main Capital Market Indices in Poland," [in:] Milo W., Wdowiński P. (eds.), Financial Markets: Principles of Modelling, Forecasting and Decision-Making, 223-41.

Nelson D. (1991), "Conditional Heteroskedasticity in Asset Returns: A New Approach," Econometrica 59, 347-70.

Ng V., Engle R. F., Rothschild M. (1992), "A Multi-dynamic Factor Model for Stock Returns," Journal of Econometrics 52, 245-66.

Schwert G. (1990), "Stock Volatility and the Crash of 87," Review of Financial Studies 3, 77-102.

Schwert G., Seguin P. (1990), "Heteroskedasticity in Stock Returns," Journal of Finance 45, 1129-55.

Verma P., Jackson O. (2008), "Interest Rate and Bank Stock Returns Asymmetry: Evidence from U.S. Banks," Journal of Financial Economics 32, 105-18.

\begin{abstract}
ARCH modelling framework of Engle (1982) and its GARCH generalization of Bollerslev (1986) gave a huge impetus to econometric model building in the field of financial time series with time-varying variance. The main idea of the models was to describe the most typical features of capital markets like volatility clustering, excess kurtosis and fat tails. As empirical evidence shows asymmetry is also a prominent feature of stock market returns volatility. The reaction of risk if stock returns go off the long run trajectory is different in case of positive and negative market news. Thus it is indispensable to employ asymmetric models being a modification of a traditional GARCH. In the paper we used an approach of Engle and Ng (1993) to test for asymmetric effects in stock indices of developed and Central European stock markets.
\end{abstract}




\section{CESifo Working Paper Series}

for full list see www.cesifo-group.org/wp

(address: Poschingerstr. 5, 81679 Munich, Germany, office@cesifo.de)

2909 Rolf Golombek, Mads Greaker and Michael Hoel, Climate Policy without Commitment, January 2010

2910 Sascha O. Becker and Ludger Woessmann, The Effect of Protestantism on Education before the Industrialization: Evidence from 1816 Prussia, January 2010

2911 Michael Berlemann, Marco Oestmann and Marcel Thum, Demographic Change and Bank Profitability. Empirical Evidence from German Savings Banks, January 2010

2912 Øystein Foros, Hans Jarle Kind and Greg Shaffer, Mergers and Partial Ownership, January 2010

2913 Sean Holly, M. Hashem Pesaran and Takashi Yamagata, Spatial and Temporal Diffusion of House Prices in the UK, January 2010

2914 Christian Keuschnigg and Evelyn Ribi, Profit Taxation and Finance Constraints, January 2010

2915 Hendrik Vrijburg and Ruud A. de Mooij, Enhanced Cooperation in an Asymmetric Model of Tax Competition, January 2010

2916 Volker Meier and Martin Werding, Ageing and the Welfare State: Securing Sustainability, January 2010

2917 Thushyanthan Baskaran and Zohal Hessami, Globalization, Redistribution, and the Composition of Public Education Expenditures, January 2010

2918 Angel de la Fuente, Testing, not Modelling, the Impact of Cohesion Support: A Theoretical Framework and some Preliminary Results for the Spanish Regions, January 2010

2919 Bruno S. Frey and Paolo Pamini, World Heritage: Where Are We? An Empirical Analysis, January 2010

2920 Susanne Ek and Bertil Holmlund, Family Job Search, Wage Bargaining, and Optimal Unemployment Insurance, January 2010

2921 Mariagiovanna Baccara, Allan Collard-Wexler, Leonardo Felli and Leeat Yariv, Gender and Racial Biases: Evidence from Child Adoption, January 2010

2922 Kurt R. Brekke, Roberto Cellini, Luigi Siciliani and Odd Rune Straume, Competition and Quality in Regulated Markets with Sluggish Demand, January 2010

2923 Stefan Bauernschuster, Oliver Falck and Niels Große, Can Competition Spoil Reciprocity? - A Laboratory Experiment, January 2010 
2924 Jerome L. Stein, A Critique of the Literature on the US Financial Debt Crisis, January 2010

2925 Erkki Koskela and Jan König, Profit Sharing, Wage Formation and Flexible Outsourcing under Labor Market Imperfection, January 2010

2926 Gabriella Legrenzi and Costas Milas, Spend-and-Tax Adjustments and the Sustainability of the Government's Intertemporal Budget Constraint, January 2010

2927 Piero Gottardi, Jean Marc Tallon and Paolo Ghirardato, Flexible Contracts, January 2010

2928 Gebhard Kirchgässner and Jürgen Wolters, The Role of Monetary Aggregates in the Policy Analysis of the Swiss National Bank, January 2010

2929 J. Trent Alexander, Michael Davern and Betsey Stevenson, Inaccurate Age and Sex Data in the Census PUMS Files: Evidence and Implications, January 2010

2930 Stefan Krasa and Mattias K. Polborn, Competition between Specialized Candidates, January 2010

2931 Yin-Wong Cheung and Xingwang Qian, Capital Flight: China's Experience, January 2010

2932 Thomas Hemmelgarn and Gaetan Nicodeme, The 2008 Financial Crisis and Taxation Policy, January 2010

2933 Marco Faravelli, Oliver Kirchkamp and Helmut Rainer, Social Welfare versus Inequality Concerns in an Incomplete Contract Experiment, January 2010

2934 Mohamed El Hedi Arouri and Christophe Rault, Oil Prices and Stock Markets: What Drives what in the Gulf Corporation Council Countries?, January 2010

2935 Wolfgang Lechthaler, Christian Merkl and Dennis J. Snower, Monetary Persistence and the Labor Market: A New Perspective, January 2010

2936 Klaus Abberger and Wolfgang Nierhaus, Markov-Switching and the Ifo Business Climate: The Ifo Business Cycle Traffic Lights, January 2010

2937 Mark Armstrong and Steffen Huck, Behavioral Economics as Applied to Firms: A Primer, February 2010

2938 Guglielmo Maria Caporale and Alessandro Girardi, Price Formation on the EuroMTS Platform, February 2010

2939 Hans Gersbach, Democratic Provision of Divisible Public Goods, February 2010

2940 Adam Isen and Betsey Stevenson, Women's Education and Family Behavior: Trends in Marriage, Divorce and Fertility, February 2010 
2941 Peter Debaere, Holger Görg and Horst Raff, Greasing the Wheels of International Commerce: How Services Facilitate Firms' International Sourcing, February 2010

2942 Emanuele Forlani, Competition in the Service Sector and the Performances of Manufacturing Firms: Does Liberalization Matter?, February 2010

2943 James M. Malcomson, Do Managers with Limited Liability Take More Risky Decisions? An Information Acquisition Model, February 2010

2944 Florian Englmaier and Steve Leider, Gift Exchange in the Lab - It is not (only) how much you give ..., February 2010

2945 Andrea Bassanini and Giorgio Brunello, Barriers to Entry, Deregulation and Workplace Training: A Theoretical Model with Evidence from Europe, February 2010

2946 Jan-Emmanuel De Neve, James H. Fowler and Bruno S. Frey, Genes, Economics, and Happiness, February 2010

2947 Camille Cornand and Frank Heinemann, Measuring Agents' Reaction to Private and Public Information in Games with Strategic Complementarities, February 2010

2948 Roel Beetsma and Massimo Giuliodori, Discretionary Fiscal Policy: Review and Estimates for the EU, February 2010

2949 Agnieszka Markiewicz, Monetary Policy, Model Uncertainty and Exchange Rate Volatility, February 2010

2950 Hans Dewachter and Leonardo Iania, An Extended Macro-Finance Model with Financial Factors, February 2010

2951 Helmuth Cremer, Philippe De Donder and Pierre Pestieau, Education and Social Mobility, February 2010

2952 Zuzana Brixiová and Balázs Égert, Modeling Institutions, Start-Ups and Productivity during Transition, February 2010

2953 Roland Strausz, The Political Economy of Regulatory Risk, February 2010

2954 Sanjay Jain, Sumon Majumdar and Sharun W. Mukand, Workers without Borders? Culture, Migration and the Political Limits to Globalization, February 2010

2955 Andreas Irmen, Steady-State Growth and the Elasticity of Substitution, February 2010

2956 Bengt-Arne Wickström, The Optimal Babel - An Economic Framework for the Analysis of Dynamic Language Rights, February 2010

2957 Stefan Bauernschuster and Helmut Rainer, From Politics to the Family: How Sex-Role Attitudes Keep on Diverging in Reunified Germany, February 2010 
2958 Patricia Funk and Christina Gathmann, How do Electoral Systems Affect Fiscal Policy? Evidence from State and Local Governments, 1890 to 2005, February 2010

2959 Betsey Stevenson, Beyond the Classroom: Using Title IX to Measure the Return to High School Sports, February 2010

2960 R. Quentin Grafton, Tom Kompas and Ngo Van Long, Biofuels Subsidies and the Green Paradox, February 2010

2961 Oliver Falck, Stephan Heblich, Alfred Lameli and Jens Suedekum, Dialects, Cultural Identity, and Economic Exchange, February 2010

2962 Bård Harstad, The Dynamics of Climate Agreements, February 2010

2963 Frederick van der Ploeg and Cees Withagen, Is There Really a Green Paradox?, February 2010

2964 Ingo Vogelsang, Incentive Regulation, Investments and Technological Change, February 2010

2965 Jan C. van Ours and Lenny Stoeldraijer, Age, Wage and Productivity, February 2010

2966 Michael Hoel, Climate Change and Carbon Tax Expectations, February 2010

2967 Tommaso Nannicini and Roberto Ricciuti, Autocratic Transitions and Growth, February 2010

2968 Sebastian Brauer and Frank Westermann, A Note on the Time Series Measure of Conservatism, February 2010

2969 Wolfram F. Richter, Efficient Education Policy - A Second-Order Elasticity Rule, February 2010

2970 Tomer Blumkin, Yoram Margalioth and Efraim Sadka, Taxing Children: The Redistributive Role of Child Benefits - Revisited, February 2010

2971 Chang Woon Nam and Georg Wamser, Application of Regionally Varying Additionality Degrees in the Practice of EU Cohesion Policy, February 2010

2972 Ali Bayar, Frédéric Dramais, Cristina Mohora, Masudi Opese and Bram Smeets, Modeling Russia for Climate Change Issues, February 2010

2973 Magnus Söderberg, Informal Benchmarks as a Source of Regulatory Threat in Unregulated Utility Sectors, March 2010

2974 Piotr Wdowiński and Marta Malecka, Asymmetry in Volatility: A Comparison of Developed and Transition Stock Markets, March 2010 